\title{
Evolution of Verse Form, Plots and Characters in English Plays (mid-16th to mid-19th centuries)
}

\section{Marina Tarlinskaja*}

\begin{abstract}
The aim of this essay is to demonstrate how the rhythmical evolution of English dramatic iambic pentameter parallelled the changes of aesthetic tastes and social values of English society from the mid-sixteenth to mid-nineteenth century. During 250 years the evolution of such features as the abundance or absence of enjambments, the use of constrained or loose iambs, and some others corresponds to the changes in the architecture of the theaters, the social structure of the audience, the manners of declamation, the complexity of poetic language, and the types of characters and plots the playwrights used.
\end{abstract}

Keywords: English dramatic iambic pentameter; evolution of grand styles; evolution of versification styles

So far the object of my research and the subject of my writings has been versification: English verse in its evolution, and the links between verse form and meaning (meter and meaning; and rhythm and meaning). In the present essay I shall try to show that the rhythmical evolution of English versification (mostly iambic pentameter) parallelled the changes of tastes and values of the society: the popular attitude towards morality, the viewers' expectations of how the playwright should portray love or villainy, and the features of dramatic personae. Such work has never been done before; the only name I can think of is Boris Yarkho, who divided the history of European tragedy into periods and determined the boundaries between them, using quantitative features. (Yarkho 2019 [1938]). Lovers and villains in early Elizabethan tragedies compared to their Baroque and post-Restoration counterparts in tragedies and tragi-comedies are quite dissimilar. The versification in Elizabethan, Baroque, post-Restoration Classicism and Romanticism plays had evolved. Was there any link between the evolution of tastes and expectations of the public, the plots and characters portrayed in the plays, and the changes in versification style?

* Author's address: Marina Tarlinskaja, Department of Linguistics, University of Washington, Seattle, Box 354340 Seattle, WA 98195-4340. E-mail: marinat@uw.edu. 


\section{English Dramatic lambic Pentameter}

The form of early New English iambic pentameter (I5) evolved relatively quickly: during the seventy years of Renaissance drama (1561-1642) the form changed from very strict iambs in early Elizabethan plays to loose verse during the time of Jacobean Baroque. After the Restoration of monarchy in 1660 (the return of Charles II as King) the verse form changed again, to a stricter form, and became even stricter during the time of Classicism, Dryden and the eighteenth century.

How do we define stricter and looser I5? The most important parameters, as we shall see, are the syllabic composition of lines, the placement of stresses and strong syntactic breaks within the line, and the types of line endings: their syllabic, accentual and syntactic particularities.

The earliest dramas written in iambic pentameter were composed by and for the members of the jurists' Inns ${ }^{1}$ and the Royal court. The first English drama composed in I5, was Thomas Norton and Thomas Sackville's "The Tragedy of Gorboduc" (1561). It was played during Christmas celebrations given by the Inner Temple in 1561 and then at Whitehall before Queen Elizabeth on January 18, 1562. Its syllabic structure was modeled on the French decasyllable with a caesura after syllable 4 , though the stressing alteration was clearly iambic (see Table 1 in Tarlinskaja 2014). Another tragedy, closely following "Gorboduc" and staged at Gray's Inn, was Gascoigne and Kinwelmarche's "Jocasta" (1566). It was a translation of a translation: the authors based their play on an Italian original "Giocasta" by Lodovico Dolce who, in turn, had reworked a tragedy by Euripides. The verse of "Jocasta", though bearing clear signs of the syllabic pattern of the Italian original, was, similarly to "Gorboduc", strict iambic pentameter, with prevailing word boundaries (caesura) after syllable 4, masculine line endings and frequent stressing on syllables 4 and 10. The stressing on syllables 4 and 10 rises to 91 and 97\% of all lines in Sackville's portion of "Gorboduc". The word boundaries after syllable 4 appear in threequarters of all lines.

A few decades later, the I5 plays descended to the lower strata of the population, replacing bear-baiting and other cruder entertainments. Compared to "Gorboduc" and "Jocasta", Kyd's "Spanish Tragedy" (1587) and Marlowe's "Tamburlaine" Part One (1588), are more relaxed in form and much more dramatic in contents, but they are still composed in relatively strict verse form.

1 The Inns of Court were four law schools in London, namely the Inner Temple, the Middle Temple, Gray's Inn, and Lincoln's Inn. 
They sported a precise count of syllables in the line, always 10, and practically no feminine endings (1.5\% of all lines in "The Spanish Tragedy" and $2.5 \%$ in 1 "Tamburlaine"). Almost all lines corresponded to a syntactic unit: we find very few enjambments. The lines had to be shouted out by a tragic actor, so that each line could get across to the audience standing there around the stage in open-air performance centers, sometimes in the inn yards. As we know, the first theaters were built without a roof, they were open to the elements.

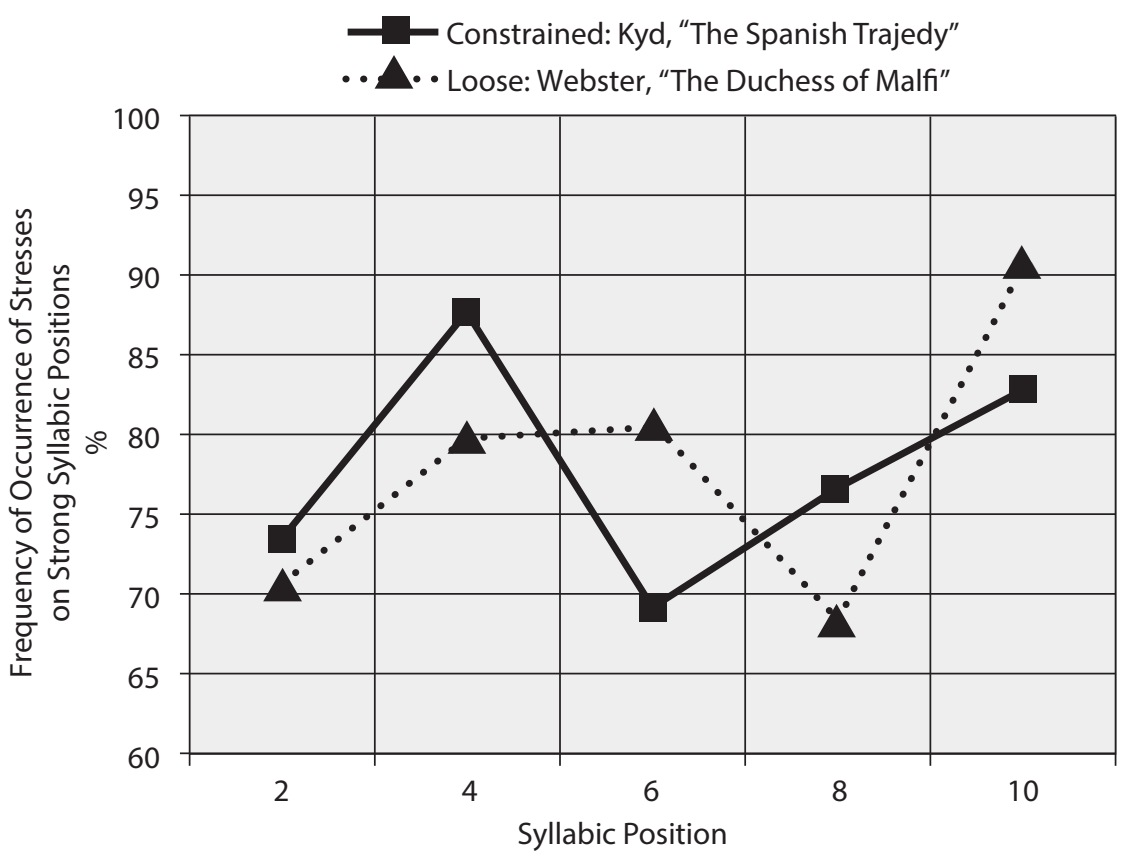

Figure 1. Stressing on S in constrained and loose iambic pentameter (in \% of all lines)

The word boundaries and syntactic breaks after syllable 4 divided the line into two even shorter portions, $4+6$ syllables. As English phrases often begin with one or more unstressed grammatical words, a syntactic break after syllable 4 (or 5) frequently caused an omitted stress on syllable 6, e. g.: "Raves in Egyptia, /5/ and annoyeth us" (Marlowe, 1 "Tamburlaine", 4.3.10). A break after syllables 6 (or 7) caused an omitted stress on syllable 8, as in "The clouds methought would open, /7/ and show riches" (Shakespeare, "The Tempest" 1.1.143). Figure 1 illustrates the contrast between constrained and loose I5, Kyd's "The Spanish Tragedy" with its minimum of stresses (a "dip") on syllable 6 and Webster's "The Duchess of Malf" (1612) with its "dip" on syllable 8. 
The verse structure began to get looser by the end of the Elizabethan epoch (1600 is conventionally considered the boundary between the two poetic styles), and it greatly changed during the Baroque period. By that time, enclosed theaters began to be built, and the need to enunciate every separate line disappeared. The tempo of declamation must have changed: the syllabic structure of verse lines lost its strict count, and two or even three syllables began to be inserted between stresses on metrically strong (S) syllabic positions. Such clusters of syllables on metrically weak (W) syllabic positions were probably recited quickly. Here is an example (clusters of syllables are in bold): "Thou hast pressed to the Emperours presence without my warrant" (Fletcher, "The Prophetess", 3.2.79): two syllables filling the same W occur in positions 1, 3, 5, 7. We also find cases when a syllable is omitted both on $\mathrm{W}$ and $\mathrm{S}$ syllabic positions. The omitted syllable sometimes accompanied an action, e. g., putting down a spoon, giving a letter, kneeling.

After 1600 the most frequent word boundary and syntactic break gradually moved closer to the end of the line and began to fall after syllable 6 or even 7. Consequently, the stressing "dip" moved from syllable 6 to syllable 8. Cf.:

He hunted well $/ 4$ / that was the lion's death

(Kyd, "The Spanish Tragedy", 1.1.170)

To that loved Duke stands next you; /7/ with the favour (Middleton, "A Game at Chess" 2.2.164)

In Kyd's line there is a break after syllable 4 and an omitted stress on six, while in Middleton's line there is a syntactic break after syllable 7 and an omitted stress on eight. Figure 1 above shows that as the stressing "dip" had moved from syllable 6 to 8 , the frequency of stressing on syllable 4 had dropped and on 6 increased: a completely different syntactic and accentual line configuration.

The structure of line endings had changed too. Numerous enjambments and feminine endings developed; for example, in Shakespeare's early "The Comedy of Errors" (1589-1590) the number of feminine endings is 13.5\%, while in his last solo play "The Tempest" (1610-1611) it is 35.6\%, and in Middleton's "A Game at Chess" (1624) it has climbed up to 59.4\%. Moreover, feminine endings began to accept stresses on syllable 11, as in "You look extreme ill; is it any OLD grief" (Fletcher, "Monsieur Thomas", 2.1.19). The stress on syllable 10 is in capitals, stressing on syllable 11 is underlined. Phrases like "OLD grief", with a stress on position 11 (probably weakened in declamation) following a stress on position 10, occur also in midline. In the same line from Fletcher's "Monsieur Thomas" we find a phrase "extREME ill" with the main phrasal 
stress on the metrically strong (S) position 4 and an adjacent, probably weakened, stress on the following metrically weak (W) syllabic position 5. I call such syncopated phrases "enclitic", as opposed to the more frequent "proclitic phrases" with a stress on W preceding the stress on S, as in "loved DUKE". The "verse-prose" opposition cultivated during early Elizabethan times weakened during the period of Jacobean Baroque, as the playwrights clearly tried to have their texts resemble regular speech, and the tempo of declamation must have quickened.

I5 of later Baroque became even more loose. Massinger, for example, sported many enjambments that combined with feminine and dactylic endings. In earlier verse, such as Fletcher's, enjambments and feminine endings were mutually exclusive: Fletcher's feminine endings required a syntactic line boundary. Here are some examples of Massinger's lines with feminine endings combined with enjambments (enjambments are marked $[\rightarrow]$ ):

They do presume they may with license practice $\rightarrow$

Their lusts and riots, they shall never merit $\rightarrow$

The noble name of soldiers. To dare boldly $\rightarrow$

In a fair cause, and for their country's safety $\rightarrow$

To run upon the cannon's mouth undaunted...

(Massinger, "A New Way to Pay Old Debts", 1.2.95-99)

In Massinger plays, accentual deviations from the meter on adjacent syllabic positions SWS were allowed and expected; e. g.: "Shrink up with sloth, nor for want of employment" (Massinger, "The Maid of Honor" 1.1.218). All these features made Massinger's dramas sound like prose; his loose rhythms were criticized by such subtle scholars as Ants Oras (Oras 1960: 26-27). Obviously, prose-sounding verse was Massinger's aim: the "verse-prose" opposition was not aesthetically valued any more and got effaced. Here are three lines from Massinger's tragedy "The Maid of Honour"):

Pray you, style me as I am, a wretch forsaken $\rightarrow$

Of the world as myself. - I would it were $\rightarrow$

In me to help you. - Ay, if that you want POWER, $\underline{\text { Sir }}$

(Massinger, "The Maid of Honour" 3.1.109-111)

Strings of two syllables occur on positions 5 and 7 of lines 109 and 111 (underlined), line 109 has a feminine ending and an enjambment, line 110 contains accentual deviations on positions SWS (2, 3, 4, in bold), and line 111 has a heavy feminine ending. Such lines would be disallowed in Shakespeare's verse. 
Cromwell's parliament closed all theaters in 1642 . Theaters were reopened after the Restoration of monarchy in 1660. King Charles II had spent his exile years at Versailles and acquired a taste for gallantry and theater. On his return to England he licensed two theater companies, one of them headed by William Davenaunt, a courtier and a second-rate playwright. French, and now English, theaters allowed women-actresses, and the actions were enlivened by the "machines" that made it possible for the angels and witches to come flying on stage. By that time the tastes and expectations of the British public had changed; the "gallant" audience needed a more refined style; Shakespeare's plays and their versification were considered barbaric.

Different tastes required different plays, and a new generation of playwrights began to create plays that suited the changed tastes. The post-Restoration playwrights lacked both talent and time: the new theaters required new plays, but new plays are not composed in a hurry, so the post-Restoration authors began to alter and rewrite later Elizabethan and Baroque plays. We shall discuss the altered plots and style below, right now let us look what happened to the verse structure of the refurbished plays. Verse was moving towards greater strictness and symmetry that will develop by the end of the seventeenth century. It was epitomized in Dryden's poetry: Dryden was the forerunner of Classicism. Syntactic breaks in, for example, William Davenant's authentic plays and alterations began to appear after positions 4 and 6 equally often, and the stressing "dip" on position 8 began to be replaced by equal stressing of syllables 6 and 8 (cf. with Shakespeare's "Henry V" 80 years previously).

The most noticeable feature of the post-Restoration plays was the smoothing out of the line rhythm: the accentual "deviations" that earlier poets used to emphasize meaning began to be ironed out. What more, the Renaissance figures of speech such as metaphors, obviously became too complicated for the new audience to understand and were simplified or removed. Here is an example. In "Macbeth" Shakespeare is describing the murder of the king. The deed was so horrible that the day became as dark as the night (obviously during a solar eclipse):

....by th' hour 'tis day,

And yet dark night strangles the traveling lamp

(Shakespeare, "Macbeth" 2.4.7)

"The traveling lamp" is a metaphorical nomination of the sun. The verb "strangles", stressed on the first syllable, occurs on positions 5-6, a rhythmical deviation from the meter and a metaphor for "covering, extinguishing". Here is how Davenant altered the line, simplifying its rhythm and removing the metaphors: 
And yet dark night does cover all the skie

(Davenant, "Macbeth" 2.4.7)

During the time of Classicism (beginning of the eighteenth century) the concept of what is beautiful had changed again and required a return to a stricter verse form and a stronger "verse-prose" opposition. Italian-style opera became fashionable, and playwrights composed librettos, also in the form of I5 as did Theobald in "Orestes". Here are some examples of the post-Restoration and early Classicism authors and plays: John Dryden's "All for Love" (1677), Thomas Otway's "Venice Preserved" (1682), William Congreve's "The Way of the World" (1700), Joseph Addison's "Cato" (1713), and George Lillo's “The London Merchant" (1731).

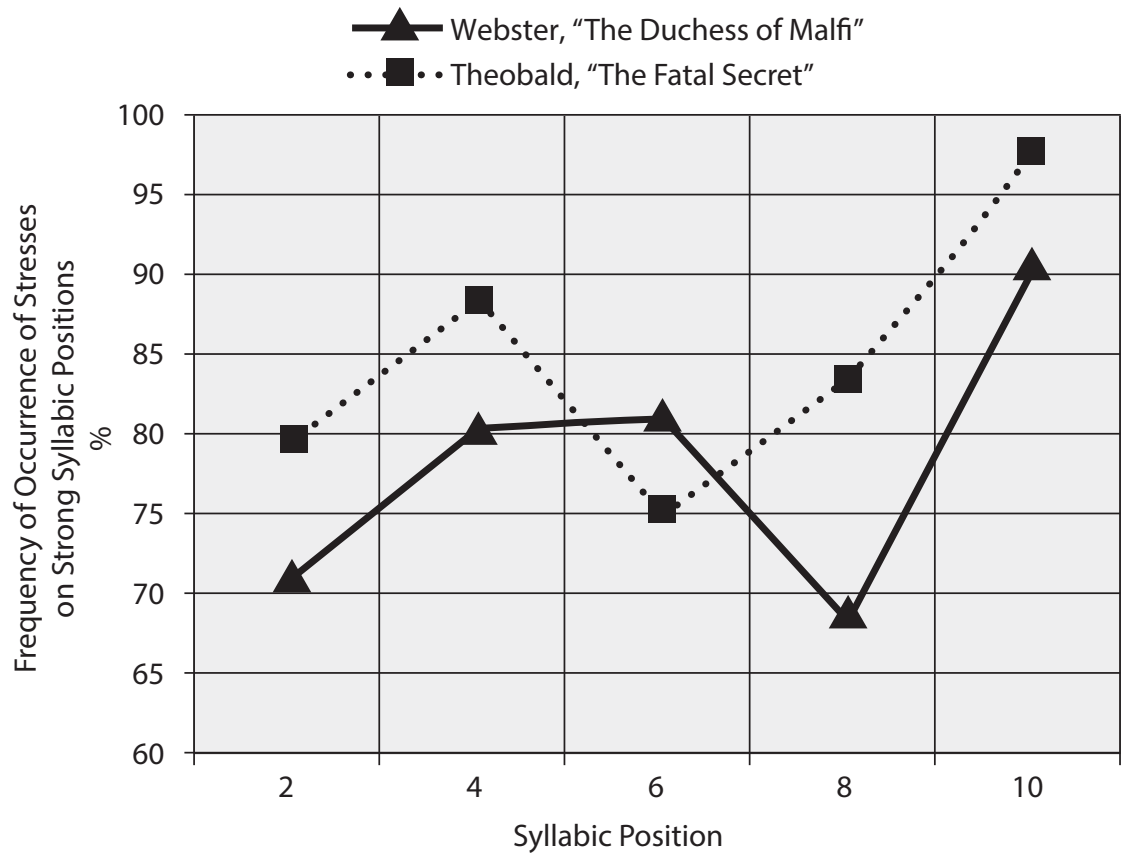

Figure 2. Stressing on S in Webster's "The Duchess of Malfi" (1612) and its adaptation by Lewis Theobald in "The Fatal Secret" (1736)

The eighteenth-century poems and plays favor a symmetrical line structure with a stressing "dip" on position 6. Rhythmical parallelism of hemistichs often accompanied grammatical parallelism, e. g.: 
With quivering Pinions, in the genial Blaze

To weeping Grottoes, and the hoary Caves

(Thomson, "Winter", 24, 76)

Figure 2 displays the stress profile of Webster's tragedy "The Duchess of Malf" (1612) and its rewritten variant by Theobald 124 years later, "The Fatal Secret" (1736). Theobald's line is structurally symmetrical, with its stressing "dip" on syllable 6, but the most noticeable changes are in the plot: the scenes of psychological torture of the duchess are omitted, the villain Bozola reforms and helps the duchess, the duchess is not murdered but survives and is reunited with her low-born but beloved husband whom she had secretly married (her "secret").

Romanticism (the end of the eighteenth and the first half of the nineteenth centuries). opposed Classicism ideologically, thematically and in the discovery of new meters. We might expect Romanticism to find new rhythms in the still widely used iambic pentameter. But the iambic pentameter of the earliest romantic play, "The Cenci" by Shelley seems to have retained some versification features of the preceding epoch, with a firm "dip" on syllable 6.

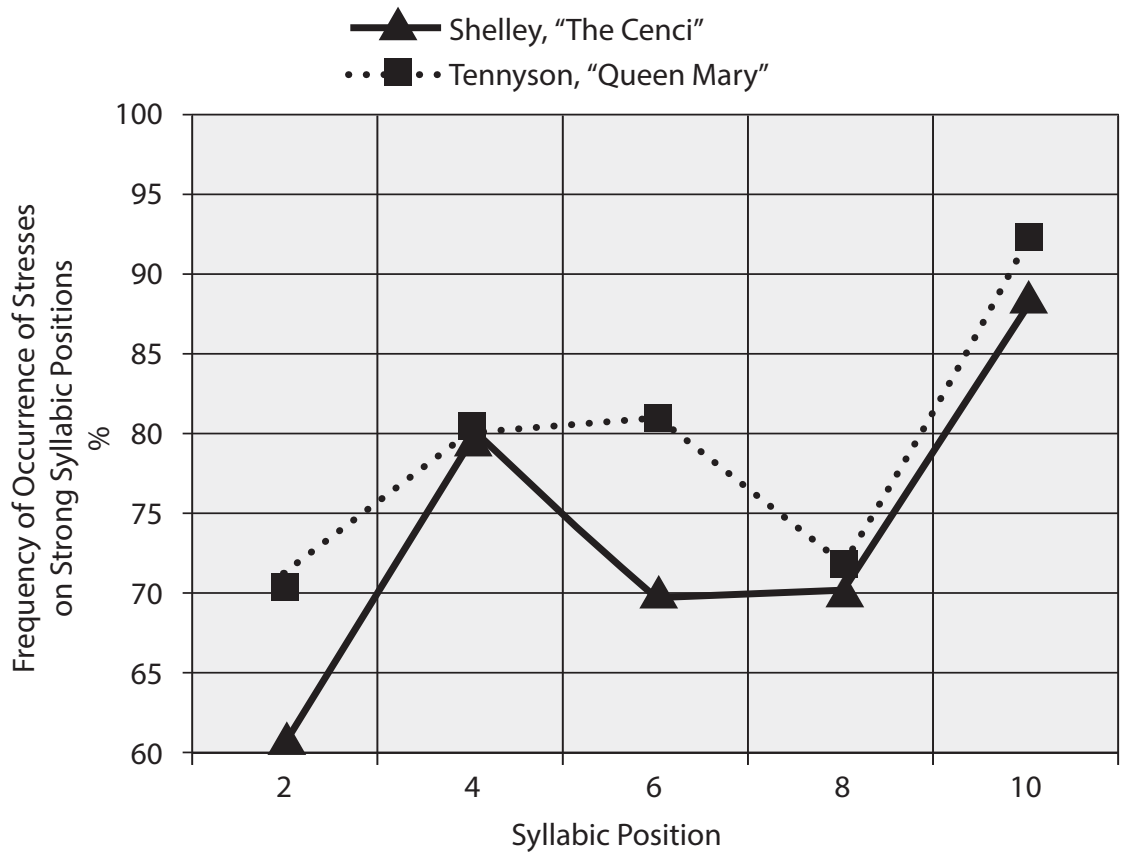

Figure 3. Stressing on S in Shelley's "The Cenci" and Tennyson's "Queen Mary" (in \% of all lines) 
Byron's "Sardanapalus", dedicated to Goethe and composed ten years later than "The Cenci", in 1821, already has a different stress profile: the stressing on syllable six is $73.8 \%$ and on position eight $70.4 \%$ : the "dip" is beginning to move to position 8. In the much later "Queen Mary" by Tennyson (1875) the "dip" on position 8 is distinct (Figure 3). "Queen Mary" is, as were Shelley's and Byron's tragedies, clearly composed in the Shakespearean mode, and in spite of its altered stress profile configuration, it retains an "Elizabethan" pattern of word boundaries and syntactic breaks after syllable 4:

Stand fast it may, /4/ but it had written last:

Those that were now /4/ her Privy Council, sign'd

Before me; nay, /4/ the Judges had pronounce

That our young Edward /5/ might bequeath the crown

Of England, putting by his father's will,

Yet I stood out, /4/ till Edward sent for me,

The wan boy-king, /4/ with his fast-fading eyes

Fixed hard on mine, /4/ his frail transparent hand...

(Tennyson, “Queen Mary”, 1.1. Cranmore’s monologue 1-9)

And one more feature of the eighteenth- and nineteenth-century dramas: they were all syllabically strict. The eighteenth century loved order and symmetry, while the nineteenth century had to oppose iambs to the new-born dolnik and, later, free verse, so the syllabic structure of the dramatic I5 through Frost's twentieth-century plays remained regular.

\section{Verse form and Tastes of the Epoch}

Verse form is only one part of a poetic work. It was determined by such seemingly unrelated features as the architecture of the theaters, and by such clearly relevant circumstances as the tastes and expectations of the public. We shall see how the changes of verse form accompanied the changes in plots of the plays and their genres, the character types and the depiction of such ubiquitous motifs as love and villainy.

Look at the theme of love as presented by Shakespeare throughout his canon. Except for the "dark lady", the lyrical heroine of the Sonnets, who seems to have been a real person, "love" in Shakespeare's works is passionate but pure (Tamora's lust for the villain Aaron in "Titus Andronicus" does not count), it often ends in a marriage, both in the comedies (Beatrice and Benedick from "Much Ado About Nothing") and tragedies (Romeo and Juliet). Sometimes lovers are already married (Othello and Desdemona, Imogen and Posthumus 
in "Cymbeline", compare with Marlowe's Tamburlaine and Zenocrate in his "Tamburlaine the Great"), or, as an alternative, one of the spouses is trying to win the love of the other (Helena and Bertram in "All's Well That Ends Well"). Lust is condemned; the object of lust is an innocent victim, a lamb (Lucrece in the poem "The Rape of Lucrece", Lavinia, raped and mutilated in Shakespeare's early tragedy "Titus Andronicus"). Recall that Elizabethan verse structure was usually strict, the syllable count was precise, the hemistich segmentation $4+6$ (or $5+5$ ) syllables was indicated by the word boundary and syntactic line segmentation, the stressing "dip" fell on syllable 6, the consequence of the syntactic line segmentation $4+6$ or $5+5$. The link between the thematic and versification preferences of the epoch is not direct but some link seems to exist.

The Queen died in 1603, and 1600 is usually considered the end of the Elizabethan epoch and the beginning of the Baroque. The term "baroque" in Medieval Italian meant an obstacle in schematic logic. Subsequently it came to denote any contorted idea or physical form, for example, a pearl of a contorted shape. The period of Baroque in England is associated with the rule of Kings James I and Charles I, the first half of the seventeenth century. Later, in an anonymous review of Jean-Philippe Rameau's opera "Hippolyte et Aricie", 1733 (based on Racine's tragedy "Phèdre") the critic complained that the music was too bizarrely "du baroque", it lacked harmony, it was full of dissonances, and its "meter" changed with an unwarranted frequency. The term "baroque" and later "rococo" were associated with a gross lack of pleasing orderliness and symmetry.

Recall how the verse structure of dramatic works had changed after 1600. It turns out that the playwrights' treatment of the plots, the major motifs ("love", for example) and the character types had also changed. The popular ideology of the British "bon monde" was based on the ideas of the French poet and philosopher Théophile de Viau (1590-1626), who himself was a follower of the Italian philosopher Lucilio Vanini. Vanini questioned the immortality of the soul; he was accused of heresy and practicing magic, after a trial in 1610 his tongue had been cut out, he was strangled, and his body was burned. Théophile de Viau who in his satires and elegies advocated a libertine and epicurean lifestyle was banned from France and at one time settled in England. Théophile de Viau's follower in England was the poet, courtier and coxcomb John Wilmot, Earl of Rochester (1647-1680). A talented poet and the most learned wit among Charles II's courtiers, he was also famous for his rakish lifestyle. Most of his works were so obscene that the young earl did not publish them during his lifetime, they were passed from one person to the next. The most famous of his works is the obscene "A Satyr Against Reason and Mankind". 
The new ideology preached permissiveness in love. Marriage began to be considered a heavy burden; homosexuality and incest became favorite motifs in the Baroque plays. Incestuous love was particularly in vogue. An example of incestuous love was the famous tragedy by John Ford "Tis Pity She's a Whore" performed between 1629 and 1633 by Queen Henrietta's men at the Cockpit theater. The plot of the tragedy is the passionate love between Giovanni and Annabella, a brother and a sister. The end is, as expected, not only tragic but also macabre.

Middleton's tragicomedy "Women, Beware Women" (1657) contains a theme of a love affair between a young uncle and his niece. The motif of incestuous love of a brother for his twin sister is hinted at in Webster's "The Duchess of Malf", and a discussion of homosexual group sex takes place in Middleton's tragicomedy "A Game at Chess" (1624).

The period of Baroque, with its decadent tastes, ubiquitous melancholy and craving for things previously abhorred and forbidden was marked by its "du baroque" loose verse. We have only discussed several features of such looseness: the syllable count, types of line endings, places of major syntactic breaks and the position of the midline stressing dip, but there were other features too. They made the Jacobean dramatic verse prose-like, and this kind of irregular verse accompanied the changed morality of the audience and the themes of the plays that appealed to the viewers.

The monarchy was restored in 1660, and the Puritan strictness of morals and behavior was replaced by the pre-Cromwellian looseness of manners and permissiveness. The new King, Charles II, who had spent his youth at the Versailles, had, as mentioned above, acquired an indelible taste for the French refined manners, gallantry, as well as arts and theater. So, on his return to England Charles II gave licenses to two theater companies. Actresses replaced boys as female leads in the English theater, and the king had several mistressesactresses. But the permissiveness did not last long. Charles II was replaced by the boring James II, and in the last quarter of the seventeenth century England returned to the old theater traditions and old playwrights, but with reservations. Classicism was approaching; the plays of the old and still revered authors had to be rewritten "for their own good", so that they should end well, the plots introduced, or emphasized, a sentimental pair of lovers, or even better, two pairs of lovers, as in Nahum Tate's adaptation of Shakespeare's "Richard II" (1680): Classicism loved symmetry. The plays were not composed for the ignorant "masses" but for the sentimental "gallant" public (Murray 2005). They had to contain a clear "moral": evil had to be punished and virtues had to triumph. The playwrights began to be guided by the principles "follow the rules". The new rules barred strong passions, they had to be replaced by 
milder feelings. The versifiers also had to observe strict rules; the critic Edward Albert instructed the playwrights to follow "strict care and accuracy in poetic technique".

The pre-Classicism English poets were greatly influenced by classical authors and contemporary French literature, particularly the tragedies by Corneille and Racine. Heroic tragedies with Ancient Greek and Roman heroes became fashionable. The main characters of such tragedies were conventional figures: men of superhuman bravery whose passion for the beloved was pure and selfless. Love and duty were at war. In the heart of the heavenly beautiful heroine, honor and duty always won, as was already foretold in the Carolinian tragedy by John Ford "The Broken Heart" (published in 1633).

The main poet of the pre-Classicism period was John Dryden. His heroic tragedies such as "The Conquest of Granada" (1670) composed in rhymed couplets and "All for Love" (1677), in blank verse as an imitation of Shakespeare's "Antony and Cleopatra" were, as it was now expected, filled with super-valiant heroes and heavenly beautiful heroines. Rhymed couplets and symmetrical line rhythm are typical features of Classicism, both in poems and some plays. Classicism loved operas; one of the most notable plays by Lewis Theobald is an opera libretto "Orestes" (1731) composed in symmetrical iambic pentameter (Tarlinskaja 2014).

Then came Romanticism with the new tastes, new themes and new verse forms. But the plays, at least by Shelley and Byron, as later by Tennyson, were composed, following Shakespearean models, in iambic pentameter. Though innovative in plot and character types, they were building on the much earlier, though transformed, features: recall their verse rhythms and their themes and motifs, created "over the head" of Classicism, reminiscent of Shakespearean Renaissance and the Jacobean Baroque, with their pure, selfless love (as in "Sardanapalus"), or sadism, incest and patricide (as in "The Cenci").

Thus, we see how during the almost 250 years that we have run through, the changes in the verse structure of the plays accompanied the changes in the tastes of the public and the evolution of the plot compositions and the character types. 


\section{References}

Murray, Barbara A. 2005. Introduction. In: Murray, Barbara A. (ed.), Shakespeare Adaptations from the Restoration Five Plays. Madison and Teaneck, NJ: Fairleigh Dickenson University Press, xv-lxxxi.

Oras, Ants 1960. Pause Patterns in Elizabethan and Jacobean Drama (University of Florida Monographs, Humanities 3). Gainesville, FL: University of Florida Press.

Tarlinskaja, Marina 2014. Shakespeare and the Versification of English Drama 15611642. Farnham, Surrey and Burlington, VT: Ashgate Publishing.

Yarkho, Boris 2019 [1938]. Speech Distribution in Five-Act Tragedies (A Question of Classicism and Romanticism). Translated by Craig Saunders. In: Journal of Literary Theory 13(1): 13-76. https://doi.org/10.1515/jlt-2019-0002 